\title{
Coastal Douglas-fir provenance variation: patterns and predictions for British Columbia seed transfer
}

\author{
Jodie KRAKOWSKI ${ }^{1 *}$, Michael U. STOEHR ${ }^{2}$ \\ ${ }^{1}$ Cowichan Lake Research Station, Research Branch, Ministry of Forests and Range, Box 335, Mesachie Lake, B.C., V0R 2N0, Canada \\ ${ }^{2}$ Research Branch, Ministry of Forests and Range, P.O. Box 9519, Stn. Prov. Govt., Victoria, B.C., V8W 9C2, Canada
}

(Received 4 December 2008; accepted 29 April 2009)

Keywords:

adaptation /

genecology /

provenance /

Pseudotsuga menziesii /

seed transfer

\author{
Mots-clés : \\ adaptation / \\ génécologie / \\ provenance / \\ Pseudotsuga menziesii / \\ transfert de semence
}

\begin{abstract}
- We evaluated performance variability in two series of provenance trials of Pseudotsuga menziesii var. menziesii. EP 480 included 16 reciprocal provenances planted from British Columbia to Oregon, measured up to age 45. EP 599.03 featured five common provenances, plus the local source, planted at 23 British Columbia sites, measured up to age 33.

- Although residual variance was high, site accounted for 31 to $60 \%$ of the volume variance, while provenance accounted for $1-6 \%$. Interactions were also significant across ages and trials. Genotypeenvironment interaction was evident in EP 599.03, but not EP 480, which may reflect differences in experimental design.

- The worst provenances always ranked low across sites and over time. No geographic or climatic (annual, seasonal, monthly) variables consistently explained patterns of volume across sites or ages, singly or in combination for either trial, similar to findings from other studies of coastal Douglas-fir. Provenances from Washington to central Oregon often performed as well as the local provenance or better at British Columbia trial sites. Populations from higher elevations, poor sites and submaritime provenances were less vigorous.

- Results support maintaining elevational and ecotypic transfer limits, emphasizing site-specific decision making, and permitting wider latitudinal transfer on similar quality sites.
\end{abstract}

Résumé - Variation des provenances côtières de sapin de Douglas : modèles et prévisions pour le transfert des semences de Colombie-Britannique.

- Nous avons évalué la variabilité des performances de provenances de Pseudotsuga menziesii var. menziesii dans deux séries d'essais. EP 480 comprend 16 provenances réciproques plantées de la Colombie-Britannique à l'Oregon, mesurées jusqu'à 45 ans. Dans EP 599.03 figurent cinq provenances communes, ainsi que la source locale, plantées dans 23 sites en Colombie-Britannique, mesurées jusqu'à 33 ans.

- Bien que la variance résiduelle soit élevée, le site a représenté 31 à $60 \%$ de la variance du volume, tandis que la provenance représentait $1.6 \%$. Les interactions ont également été significatives dans les âges et les essais. L'interaction génotype-environnement est évidente dans EP 599,03, mais pas dans EP 480, ce qui peut refléter des différences dans la conception expérimentale.

- Les mauvaises provenances sont toujours classées bas à travers les sites et au cours du temps. Aucune variable géographique ou climatique (annuelle, saisonnière, mensuelle) n'a constamment expliqué les modèles de volume à travers les sites ou les âges, séparément ou en association pour n'importe lequel des essais, similairement aux résultats d'autres études sur les provenances côtières de sapin de Douglas. Les provenances de l'État de Washington jusqu'au centre de l'Oregon sont souvent aussi bien performantes que la provenance locale ou meilleures dans les sites d'essais en Colombie-Britannique. Les populations des plus hautes altitudes, des sites pauvres et les provenances sub-maritimes ont été moins vigoureuses.

- Les résultats sont en faveur du maintien de transferts altitudinaux et écotypiques limités, en mettant l'accent sur une prise de décision spécifique au niveau du site, et en permettant un transfert latitudinal plus grand sur des sites de qualité semblables.

\footnotetext{
* Corresponding author: jodie.krakowski@gov.bc.ca
} 


\section{INTRODUCTION}

Coastal Douglas-fir (Pseudotsuga menziesii var. menziesii (Mirb.) Franco) has been highly valued for wood volume and quality on the Pacific Northwest coast since the advent of industrial forest harvesting. Its durable, disease-resistant wood, rapid growth, and pioneer establishment make it ideally suited for rapid reforestation and flexible forest management options. The coastal variety exhibits adaptational clines in elevation at the local scale (e.g., Campbell, 1979; Sorensen, 1983); however it has a broad environmental amplitude along the coast due to the relatively homogeneous climate dominated by the moderating influence of the Pacific Ocean (Klinka et al., 2000; Ying, 1990).

Provenance studies on Douglas-fir have been ongoing for five decades in British Columbia (B.C.) (Ching and Bever, 1960; Irgens-Moller, 1957). In collaboration with agencies in the Pacific Northwest, data gathered from a range of provenance trials have been incorporated into management guidelines (Campbell, 1986; Stonecypher, 1990). Evaluating trials near rotation age fills a gap in predictions based on analysis of growth patterns of younger trees, as selection-harvest age correlations strengthen over time (White and Ching, 1985). Earlier studies found considerable rank changes among provenances (Ching and Hinz, 1978; Rowe and Ching, 1973), which would lead to some early selections underperforming by rotation age.

In B.C., coastal Douglas-fir is currently managed using three major seed planning zones. Within these zones, seed transfer currently is permissible across the lower elevation zones spanning $700 \mathrm{~m}$ elevation around the collection point and asymmetrically up to $3^{\circ} \mathrm{N}$ and $2^{\circ} \mathrm{S}$, but in the higherelevation more continental zone, latitudinal transfer is more conservative at $2^{\circ} \mathrm{N}$ and $1^{\circ} \mathrm{S}$ (Province of B.C., 2005). Delineation of and transfer between these zones is currently in transition to address anticipated impacts of climatic change on forest genetic resource management (Spittlehouse, 2008). Adaptation to and mitigation of climate change impacts via seed transfer can be guided by the results of provenance studies (Hamann and Wang, 2005; Mátyás, 1994; St. Clair and Howe, 2007; Wang et al., 2006a).

To support seed transfer objectives over the medium term (30-60 years), we use two series of long-term provenance trials to assess patterns of adaptation in coastal Douglas-fir in B.C.

\section{MATERIALS AND METHODS}

\subsection{Trial establishment}

\subsection{1. $E P 480$}

Experimental Project (EP) 480 is a series of four out of sixteen initial reciprocal provenance trials established in 1957 through cooperating agencies in British Columbia, Washington and Oregon un- der the auspices of Kim Ching (see Ching and Bever, 1960, for details). Each of the 16 provenances was planted at all 16 sites (Tab. I, Fig. 1b). Personnel and administrative changes limited the continuity of the study, but we gathered data from four of the five British Columbia trials to complement the results of EP 599.03 (Fig. 1a; see below).

Seeds were collected from 14 to 89 trees per provenance within a $40-\mathrm{km}$ radius and $200 \mathrm{~m}$ elevation. Seeds were stratified, germinated, and grown in typical nursery culture, then thinned to a uniform density (see Ching and Bever, 1960). Surplus smaller seedlings were used to replace dead seedlings after initial outplanting. Sites were clearcut and slashburned, and established using a completely randomized block design. At Nimpkish and Robertson site preparation included stump removal and some blading. The 16 provenances were laid out in $7 \times 7$-tree square plots surrounded by two rows of buffer trees at 1.8-m spacing, with four blocks per site. Table I and Figures $1 \mathrm{a}$ and $1 \mathrm{~b}$ show further details. Sites were evaluated periodically for height, diameter, form, health, and survival. Despite fencing and other control measures, some early browse damage was observed at each site (by grouse, blacktail deer, and hares). Control measures were implemented on a site-specific basis, replacement seedlings were planted, and after the first several years of growth damage was minimal and all survivors were evaluated. Nimpkish and Haney were thinned systematically in 1976 to 25 trees per plot.

\subsubsection{EP 599.03}

This trial was part of a provenance experiment series initiated in 1968 to conduct genecological research on Douglas-fir. Series 599.03 was specifically designed to delineate boundaries for seed transfer (Schmidt, 1967). Seeds were collected in 1966 from 22 populations in the species' coastal range, including seven sites in the drier rainshadow of the Coast Mountains and one site (Hoh River) from Washington State, USA Collections for each provenance occurred on sites with uniform soils and climate, within $75 \mathrm{~m}$ elevation. Most sites had the local provenance plus five common provenances planted, for a total of six per site (Tab. I, Fig. 1b). These provenances were selected to represent a wide range of climates: D'Arcy (Coast-Interior transition), Duncan (dry south Coastal), Hoh River (wetter south Coastal), Jeune Landing (wetter mid Coastal), and Noieck Creek (northern Coastal). Seeds were stratified and sown beginning in 1967 and nursery assessments were conducted. Four series of trials were established from 1969 to 1975.

Sites were clearcut and subjected to slashburning and/or other site preparation (e.g., windrows, piling) prior to planting $2+0$ seedlings at $3 \mathrm{~m} \times 3 \mathrm{~m}$ spacing, and vegetation was mechanically controlled as needed. Four sites were thinned (Tab. I). Trees were planted in four randomized complete blocks of 35-tree-row plots per provenance. Sites were assessed periodically for growth, survival, form, and health. Data measured or interpolated at age 10, 20, and 30 are presented here for comparison.

\subsection{Data analysis}

All sites were measured at different ages and for different traits. To standardize this information, individual tree data for height, diameter, and volume at ages 10, 20, 30, and 40 (age 40 for EP 480 only) were 


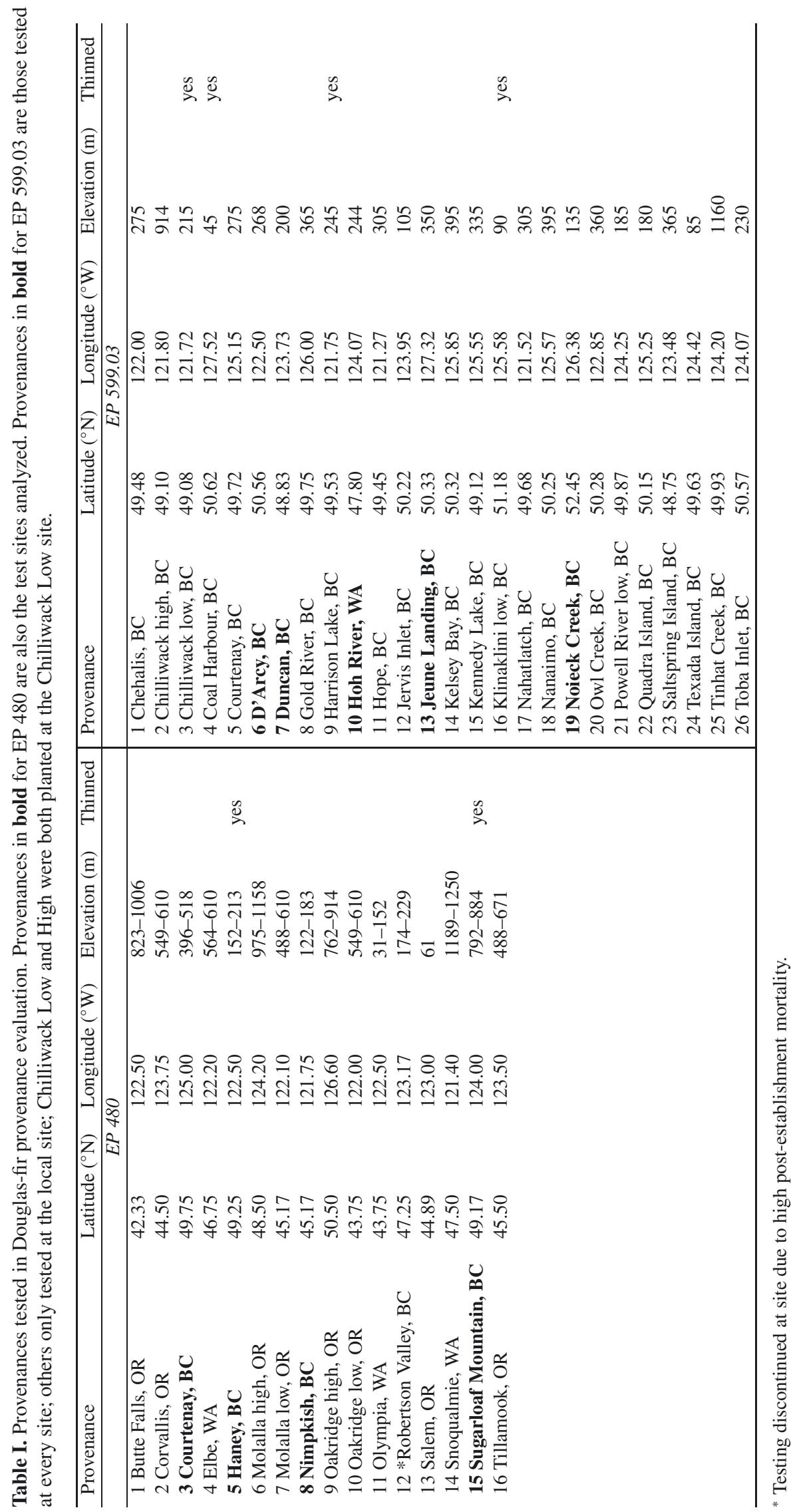




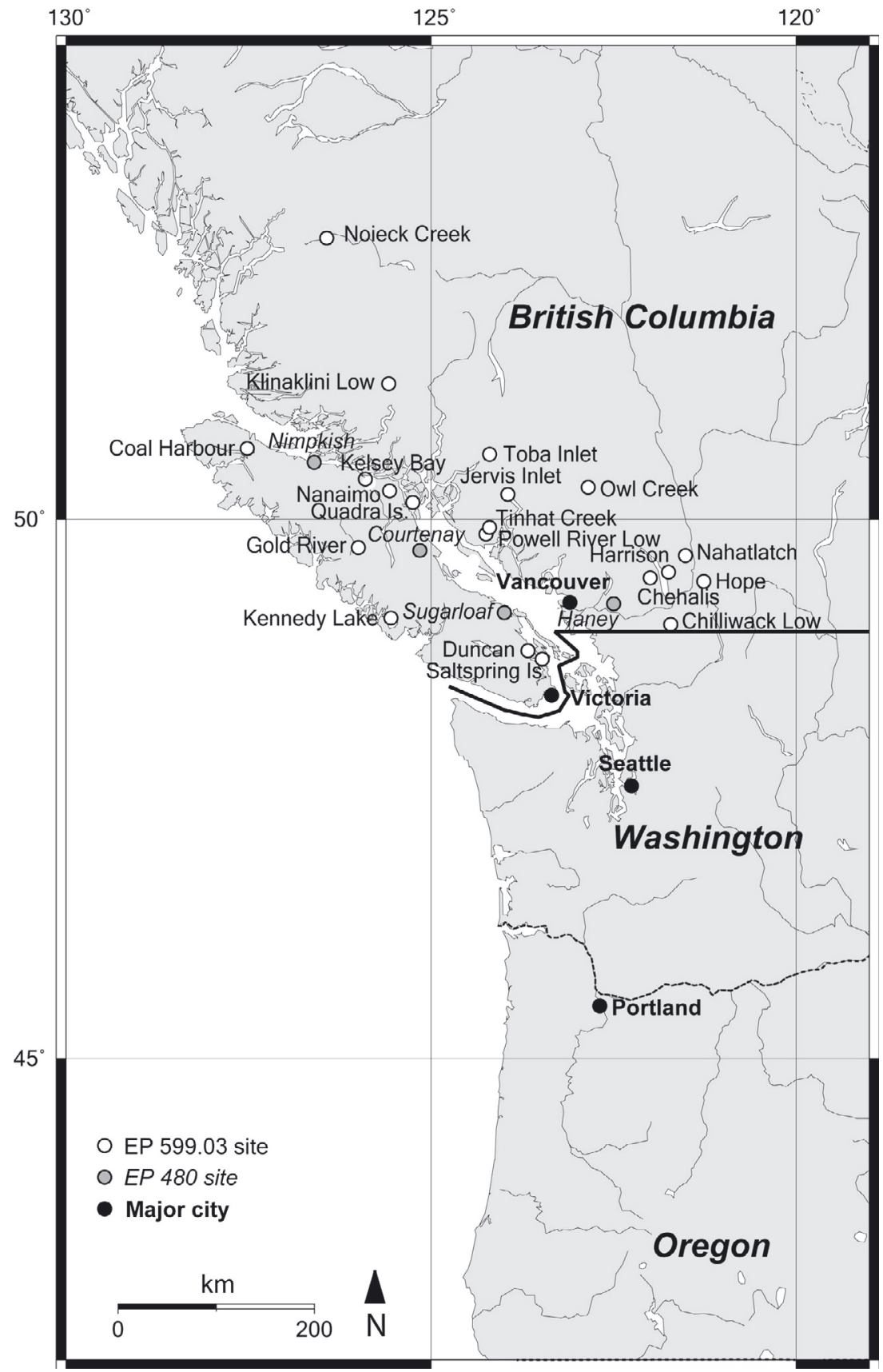

Figure 1. (a) Test sites for Douglas-fir provenance trials EP 599.03 (white circles) and EP 480 (grey circles and italic text); Courtenay was included in both trials.

interpolated based on individual tree and site mean growth functions up to age 33 (EP 599.05) or 45 (EP 480), using periodic annual increment where there was no measurement for the target year. Thinning of some sites precluded interpreting survival and diameter data only or combining this data into a site-based productivity measure, such as volume per hectare, since basal area would be inconsistently affected across sites and provenances. The B.C. Ministry of Forests individual tree immature (younger than 120 y) Douglas-fir gross volume equation for the Coast Forest Region was used to calculate singletree volume from height and diameter at $1.3 \mathrm{~m}$ (Eq. (1)). This metric was developed using naturally regenerated, well-stocked stands, and is representative of the conditions on the study sites.

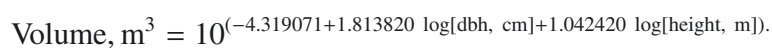

The following mixed linear model (Eq. (2)) was used to analyze the variance components and estimate best unbiased linear predictors of the response variables for each assessment year:

$$
V_{i j k l}=\mu+S_{i}+S(B)_{(i) j}+P_{k}+P S_{i k}+S P(B)_{(i) j k}+\varepsilon_{(i j k) l}
$$




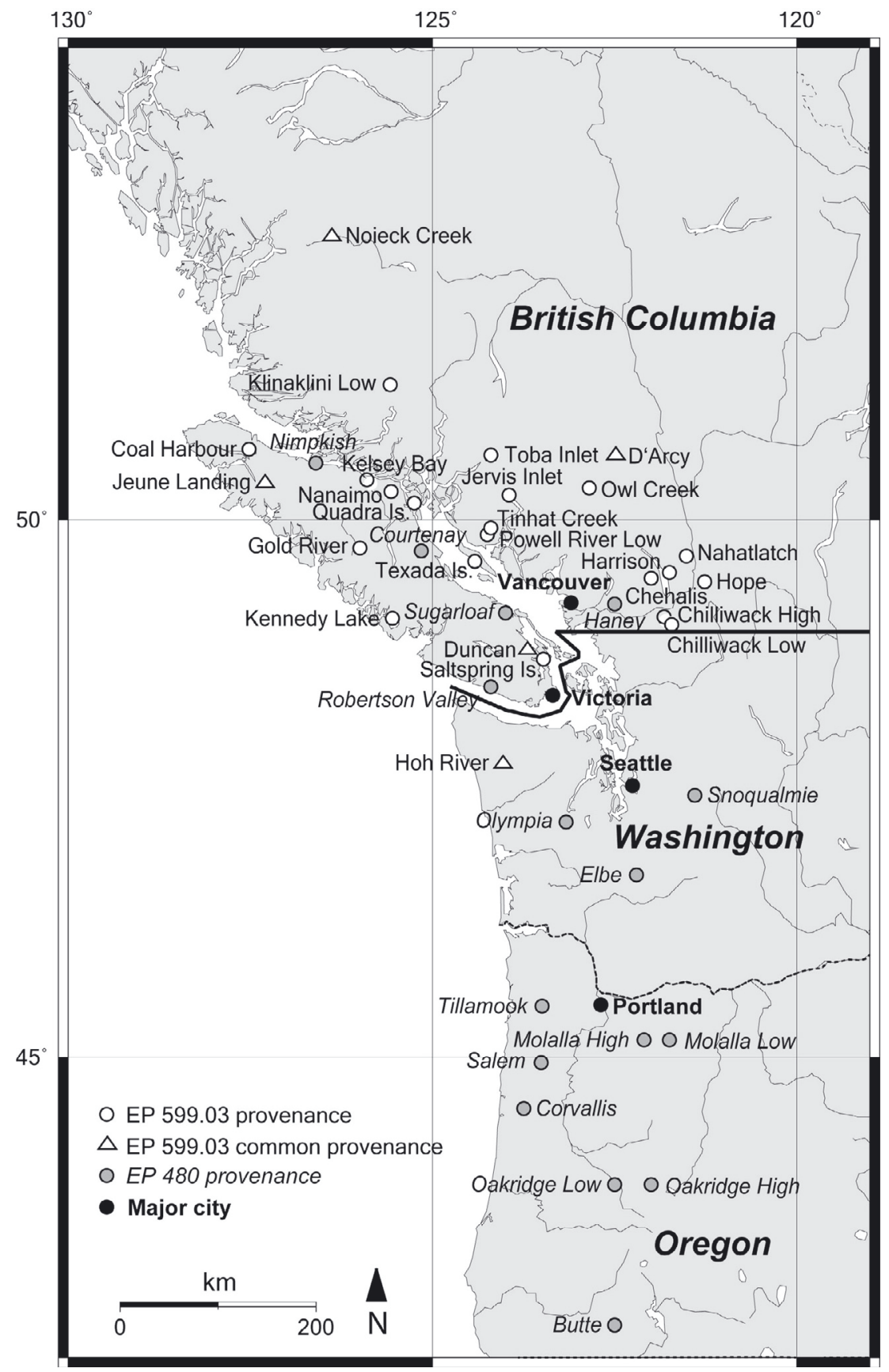

Figure 1. (b) Sources tested in Douglas-fir provenance trials EP 599.03 (white circles; white triangles for common provenances tested at all sites) and EP 480 (grey circles and italic text); Courtenay was included in both trials.

where $V$ is volume at a given age for the $l$ th tree ( $\varepsilon$ is the residual single-tree error) in the $k$ th provenance $(P)$ in the $j$ th block $(B)$ nested within the $i$ th site $(S)$. All model terms are random except for the fixed intercept, since both the provenances and test sites represent a representative range of locations used to infer performance at other locations. A subset of this model was used to test responses at individual sites. Proc Mixed of SAS V.9.1 was used to estimate variance components and significance of model terms, as well as generate BLUP (best linear unbiased prediction) values for parameters. All significance tests were based on a criterion of $\alpha=0.05$. Changes in rank across sites, provenances, and regions were also compared over time by provenances and sites. Results for height and volume were similar; only volume is presented here.

Categorical individual tree assessments indicated that higher elevation sites had a substantial amount of damage and mortality due to snow and early frost (data not shown). This effect was confounded by poor site quality where substrates were thin and nutrients and moisture limiting (M. Stoehr, unpublished data; P. Courtin, unpublished 
Table II. Variance components as a percentage of total model variance for EP 480 and 599.03; significant parameters $(P \leq 0.05)$ in bold.

\begin{tabular}{|c|c|c|c|c|c|c|c|}
\hline \multirow[b]{2}{*}{ Source of variation } & \multicolumn{4}{|c|}{ EP 480} & \multicolumn{3}{|c|}{ EP 599.03} \\
\hline & Age 10 & Age 20 & Age 30 & Age 40 & Age 10 & Age 20 & Age 30 \\
\hline Site & 30.08 & 50.67 & 55.43 & 59.48 & 48.19 & 41.46 & 35.66 \\
\hline Site $\times$ Provenance & 1.18 & 0.73 & 1.87 & 0.94 & 2.04 & 4.58 & 5.74 \\
\hline Block $($ site $) \times$ Provenance & 7.98 & 5.02 & 3.60 & 2.44 & 1.84 & 1.80 & 1.61 \\
\hline Residual & 54.53 & 40.79 & 32.81 & 33.47 & 41.88 & 45.05 & 49.26 \\
\hline
\end{tabular}

data). Snow-prone sites had high proportions of stems with leader damage, forked stems, and toppled trees, even at nutrient-rich locations that sustained productive tree growth (data not shown).

Growth response functions were developed for each site using Proc Reg of SAS to examine the variability in volume growth data explained by climate variables (Wang et al., 2006a). ClimateBC V.3.2 (Wang et al., 2006b) was the tool used to generate regional climate data using a range of climate normals to produce a suite of annual, monthly, and seasonal variables which included estimated and squared values of mean, minimum and maximum temperatures and precipitation, growing degree days, budburst date, frost free period, heat-moisture index, and continentality index. The MAXR option was used to select the combination of linear or quadratic values of each variable that fit the best model. Variables were included or excluded based on $\alpha=0.05$ criterion. Dr. Wang kindly provided data for southern sites via a beta version of his extended model ClimateUS.

\section{RESULTS}

\subsection{Provenance performance}

Site accounted for the highest proportion of variation in volume, increasing over time in EP 480 but decreasing in EP 599.03 (Tab. II). Although site accounted for up to $59.5 \%$ of variance in EP 480, it was still never significant in that trial, while site was significant for EP 599.03. The term accounting for the next highest proportion of variance was the residual error, which decreased over time in EP 480, and increased over time in EP 599.03 (Tab. II). Very high residual variance was also found during earlier analyses of EP 480 (Ching and Hinz, 1978; White and Ching, 1985). Provenance-by-site interactions were always significant for block nested within site.

Type $B$ genetic correlations to evaluate genotype $\times$ environment $(\mathrm{G} \times \mathrm{E})$ interactions $\left[\sigma_{p}^{2} /\left(\sigma_{p}^{2}+\sigma_{p x s}^{2}\right)\right]$ (Burdon, 1977) varied from 0.59 to 0.35 for EP 480 across ages. Although high, it was not always significant as provenance variance was significant only for ages 10 and 40, while provenance-by-site variation was significant only for ages 30 and 40 (Tab. II). For EP 599.03 , type B correlations ranged from 0.51 to 0.58 , reflecting the significant variance components for provenance and provenance-site interaction at all ages (Tab. II).

Site quality factors affected volume growth across sites more than geographic factors (Figs. 2, 3), as found by earlier studies (Ching and Hinz, 1978; White and Ching, 1985). This was particularly evident at the Haney site of EP 480, which had, on average, triple the volume of the other sites, with Nimpkish, Sugarloaf, and Courtenay, respectively showing lower volumes for the same provenances (Fig. 3). Both trials had plots in locations near Courtenay, which yielded very different volumes from provenances planted in the same general area on two different sites (see Figs. 2 and 3). A few sites had qualitative and quantitative soil and site data (P. Courtin, unpublished data). The quantitative variables carbon to nitrogen ratio and mineralizable nitrogen, and the qualitative variables soil nutrient regime and soil texture, all showed linear relationships with site volume $\left(R^{2}>0.1\right)$; however, the small number of sites with soil data precluded further analyses.

The five common provenances tested at all sites of EP 599.03 were assessed (Fig. 4), and all 16 provenances were ranked across the four sites for EP 480. In general, there were substantial rank changes for provenances across all sites between ages 10 and 20, with fewer changes, and changes of lesser magnitude, after age 20 . Volume performance at age 30 or 40 would not be accurately predicted by rank based on volume at age 10 . There was typically little quantitative difference among the higher ranked provenances, although the lowestranking provenances were generally statistically smaller than the best ones (Figs. 2, 3). Most of the provenances from higher elevations, limited productivity sites, and the Submaritime seed planning unit exhibited poorer performance across sites. Consistently low-ranking provenances were evident, but there were few consistently high-ranking provenances: most tended to change ranks within the top $2 / 3$ throughout the assessment period.

The same types of trends were apparent for EP 480. The worst provenances were always at or near the bottom, while the intermediate and best provenances changed ranks over time and across sites. Butte Falls and Snoqualmie always ranked low. Provenances from the rest of Oregon and B.C. all performed well at different sites, while the three Washington provenances tested were typically intermediate (Elbe, Olympia) and low (Snoqualmie). At the higher elevation site Sugarloaf Mountain, all B.C. provenances were outperformed by Oregon provenances.

Northward seed transfer, demonstrated in EP 480 by transferring Oregon and Washington provenances up to 8 degrees north, elicited variable responses, both by site and provenance. Provenances from Oakridge (both originating below $850 \mathrm{~m}$, $43.75^{\circ} \mathrm{N}$ ) performed moderately, doing substantially better on poorer than on richer sites. The Butte Falls population $(910 \mathrm{~m}$, $42.33^{\circ} \mathrm{N}$ ) had poor growth at all sites. The high elevation Snoqualmie population grew poorly, which is consistent with 


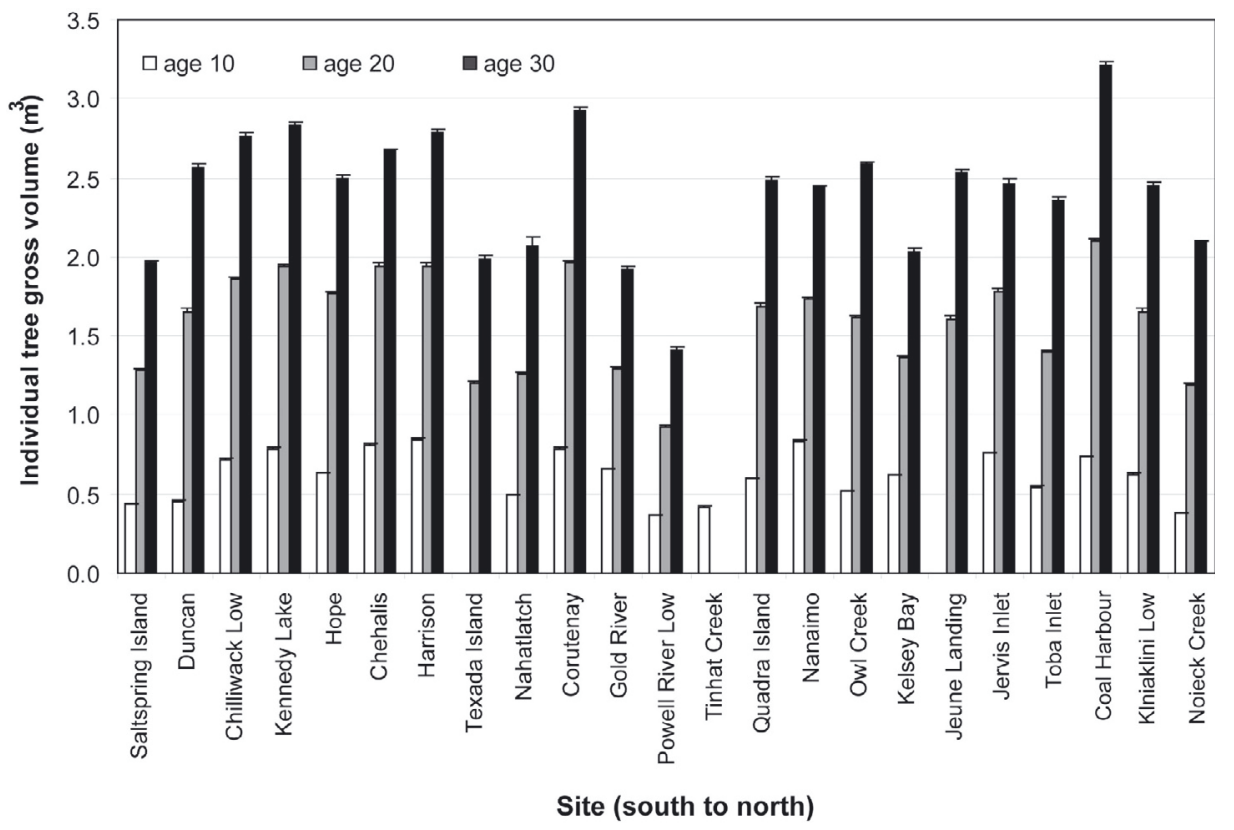

Figure 2. Site mean and standard error of individual-tree volume at age 10, 20, and 30 for EP 599.03. Bars missing where data was lacking.

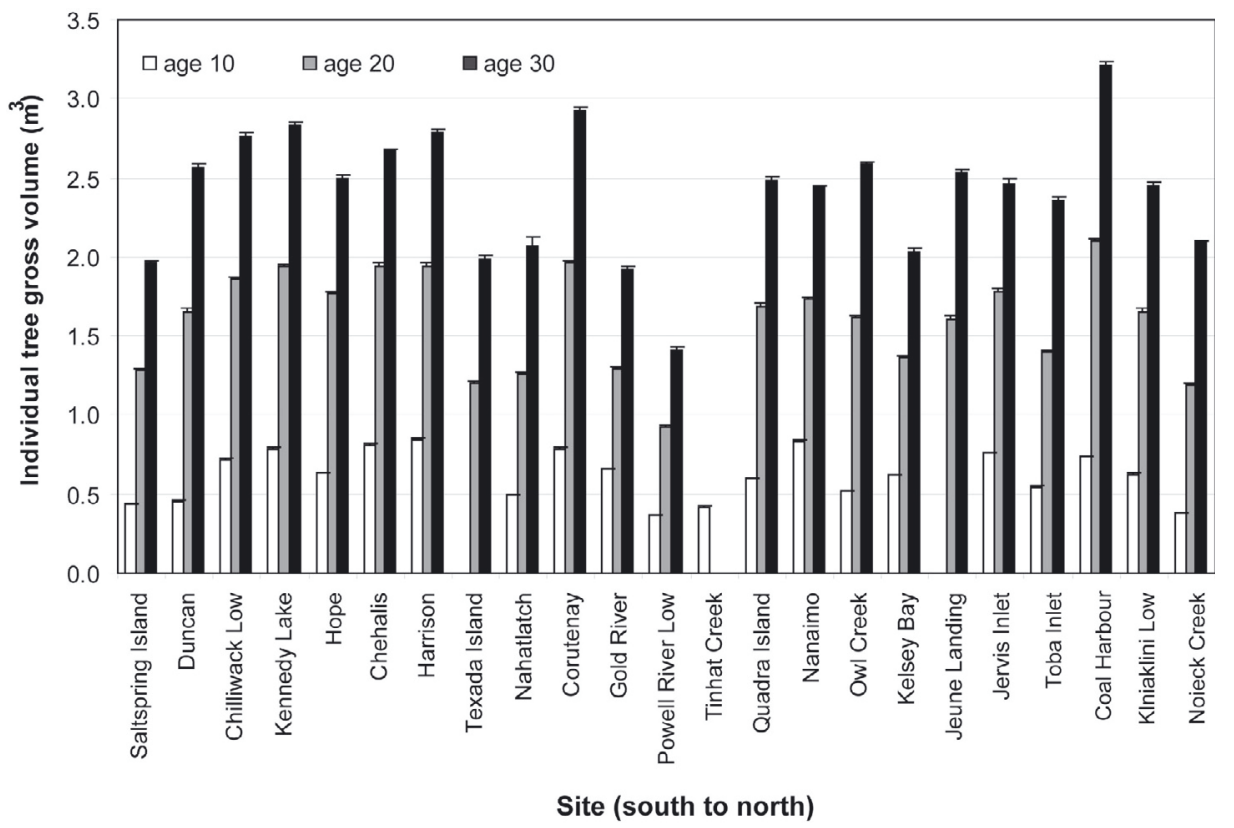

Figure 3. Site mean and standard errors for single-tree volume at age 45 (EP 480); arrows indicate local provenances.

results from EP 599.03 that reflect poor growth from higher elevation seed sources, except for the Molalla High population $\left(1070 \mathrm{~m}, 45.17^{\circ} \mathrm{N}\right)$. The Corvallis population did quite well at most sites, typically ranking in the top half, representing a seed transfer of $4-5^{\circ} \mathrm{N}$.

Overall, the key findings were that local provenances did not always perform best at a site, and that provenances from relatively distant origins (e.g., central Oregon) often grew as well or better than the local seed source (Figs. 2, 3). Submaritime sites and provenances had the poorest overall vol- ume growth and survival, and consequently the highest variability. Maritime sites supported higher volumes, particularly on the richest sites. Drought-prone sites had fairly high mortality and damage, and supported less volume growth. Over time, provenances that performed the best early on did not always keep their top ranks in later assessments. Submaritime and higher elevation provenances grew larger at richer sites than at their locations of origin, but were ranked best at sites environmentally similar to their sites of origin, where lowerelevation and coastal provenances fared poorly. 


\subsection{Geographic and climatic trends}

Relationships between volume and climate variables were tested separately by age (10, 20, and 30) and site for EP 599.03 and EP 480 (including age 40). Regression analysis was conducted using climate normals for 1971-2000 for EP 599.03 and 1961-1990 for EP 480, respectively, since these periods corresponded with most of the measurements. No consistent trends were evident either using linear or quadratic equations (data not shown). The explanatory variable that was included in significant regressions most often was annual heat:moisture index, which represents a ratio of mean annual temperature to precipitation and mean summer precipitation. Significant variable combinations changed with age and across sites; variables and their squared values were both represented in the range of equations. There were no clear trends regarding dominant influence of moisture, temperature, seasonality, or elevation.

Using the same five common provenances in EP 599.03, univariate linear and quadratic correlations with individual climatic variables were generally weak (data not shown), with a maximum $R^{2}$ of only 0.15 (longitude, quadratic regression); most variables yielded $R^{2}$ values of zero. Volume for EP 480 showed the same lack of trends and relationships with climatic and geographic variables as EP 599.03.

\section{DISCUSSION}

\subsection{Provenance variation}

Despite the high proportion of variance due to site in EP 480 , the lack of statistical significance may have been due to the heterogeneous geographic and ecological range of seed sources in EP 480, also observed in earlier assessments (White and Ching, 1985). The inconsistent genotype-environment interaction found in this study confirms earlier assessments at ages 20 and 25 (Ching and Hinz, 1978; White and Ching, 1985) that found negligible interactions in the same study, but attributed the non-significant finding to factors including ontogenetic gene expression, thinning regime, and wide seed collection area for each provenance that could homogenize or increase the variances (White and Ching, 1985). Although earlier studies found some significant interactions for individual provenances, overall there was no significant $\mathrm{G} \times \mathrm{E}$. Conversely, in the EP 599.03 trial, significant $\mathrm{G} \times \mathrm{E}$ was observed. This could be due to differences in experimental design and variances between the studies. EP 480 evaluated more widely adapted provenances, but they were only tested at four test sites, which were more similar than the 23 sites in EP 599.03. The latter trial also had more statistical precision to discern significant differences for $\mathrm{G} \times \mathrm{E}$. Many studies of seedlings and juvenile coastal Douglas-fir found pronounced $\mathrm{G} \times \mathrm{E}$ in growth and adaptive traits (e.g., Campbell, 1986; Christophe and Birot, 1979; Hermann and Lavender, 1968; St. Clair et al., 2005).

Top provenances varied widely in rank and growth potential with site characteristics. The worst performers were consistently inferior, similar to results found at age 25 (White and Ching, 1985). At age 20 there was a more marked separation between the top and remaining provenances (Ching and Hinz, 1978. The top $2 / 3$ of provenances all ranked in the top $50 \%$ at some point in their development. Variability in climate, stand management, and forest health over a rotation warrants retaining the better ranked provenances as a potential buffer against environmental variation. The poorest performers on these primarily maritime test sites were typically populations that originated in submaritime areas, implying a strong ecotypic distinction driving adaptive differentiation between these seed planning units. Similar observations were made by IrgensMoller (1957) and Hermann and Lavender (1968), who suggested this effect was a possible adaptation to spring frost in higher-elevation sites that does not develop at low elevations.

Differences in relative growth must be compared within the context of absolute growth: for example, often there was little quantitative difference between the 7 th and 15 th ranked provenances, similar to observations at age 25 (White and Ching, 1985). Rank must not be used as a selection criterion without considering the relative value and precision of the growth trait as well, and also comparing the test site and origin environments.

Several reasons may explain the lack of significant correlations between volume growth and climatic or geographic variables. The most likely reason is that the regional climate model does not accommodate fine-scale variability due to site factors, such as soil, topography, drainage, or aspect. These factors all influence species' ecological dynamics and performance, but the climate projections would have to be adjusted empirically for each site to incorporate their effects. The lack of trends may also be partly an artefact of the designs of the studies, where EP 480 sampled few provenances that originated over wide collection areas, and only four sites were assessed here of the original 16. EP 599.03 included a wide range of climates from the B.C. portion of the range, but sampled from a relatively restricted portion of the overall range of the coastal variety, which extends well into California. Geographic clines, often at fine scales, have been found in many adaptive traits in other studies in different sections of the range of Douglas-fir (Campbell and Sugano, 1993; Hermann and Lavender, 1968; St. Clair et al., 2005). These findings are frequent for seedlings and do occur in mountain and interior populations (including var. glauca, which hybridizes with var. menziesii) (Rehfeldt, 1977), but far less so for mature trees.

In the 1950's and 1960's when these experiments were established, the objectives were focused on finding sites and populations that would best characterize good growth of Douglasfir. Therefore, sites were relatively homogeneous overall in terms of site characteristics: planting sites included only a few poor sites, generally excluding those that would comprise the ecological margins of the species' range (White and Ching, 1985). This limits the statistical power of these studies to delineate relationships with climatic variables since only the middle (optimal) portion of a response and corresponding transfer function data set would be represented by these sites (O'Neill et al., 2008; Wang et al., 2006a). Contemporary approaches to delineating seed transfer zones would take these extremes into account and aim to develop robust transfer functions based on generating yield curves with sufficient data 
towards the anchor points of the curve for each ecological unit or transfer zone to effectively delineate the climatic envelope for current and future projections of growth and yield (Wang et al., 2006a).

\subsection{Implications for seed transfer}

St. Clair et al. (2005) found a mosaic of similarly adapted but non-contiguous populations across the landscape. The species is much more uniformly distributed with fewer topographic discontinuities in the current study. Since trends in volume growth with elevation, latitude, and climatic variables were not significant and did not show consistent patterns among sites in this study, the current deployment strategy of broad seed transfer on suitable sites within the Maritime and within the Submaritime seed planning units of B.C. should not compromise current or future growth potential of Douglasfir. Since effects including site and interactions with site were typically significant, site selection is important for effective deployment and capturing gains from improved material. Transferring seed too far northward has been shown to be detrimental over the short to medium term (e.g., from central or southern Oregon to B.C.), while Washington and even some northern Oregon provenances seem well adapted based on volume growth over 30 to 40 y (Figs. 3, 4).

Over the range of coastal Douglas-fir, climate change projections anticipate warming of mean and minimum temperatures, accompanied by slightly increased mean annual precipitation but with more frequent summer drought (Spittlehouse, 2008). Over the medium to longer term (50-100 y), these conditions resemble those of sites several hundred metres in elevation lower, and up to $5^{\circ}$ latitude south (e.g., Hamann and Wang, 2006; St. Clair and Howe, 2007). Retaining the current delineation between the maritime and submaritime zones is warranted; however, some of the consistent top performers across sites, including many between $50-350 \mathrm{~m}$, were those from higher elevations, such as Chilliwack High and Molalla High.

The dry Georgia Lowlands seed planning zone occupies a very restricted area around the Fraser River Basin and Puget Sound, generally corresponding to the Coastal Douglas-Fir (CDF) biogeoclimatic zone ${ }^{1}$, characterized by mild, wet winters with a pronounced summer moisture deficit (Nuszdorfer et al., 1990). Climate envelope models for a range of scenarios predict this zone will increase in extent and elevation, and may expand northward (Hamann and Wang, 2006). Adaptation and seed planning studies for this zone have generally been grouped in with the adjacent, wetter Maritime unit (Ying, 1990. Although only two populations in this study were within the CDF zone (Texada and Saltspring), they varied markedly in performance overall and from year to year. It is recommended that further studies within the dry Maritime seed planning zone focus on developing robust transfer guidelines over the next rotation with respect to drought stress tolerance for

${ }^{1}$ For further information on ecosystem classification and nomenclature in B.C., refer to the Ministry of Forests and Range BEC WEB: http://www.for.gov.bc.ca/hre/becweb/
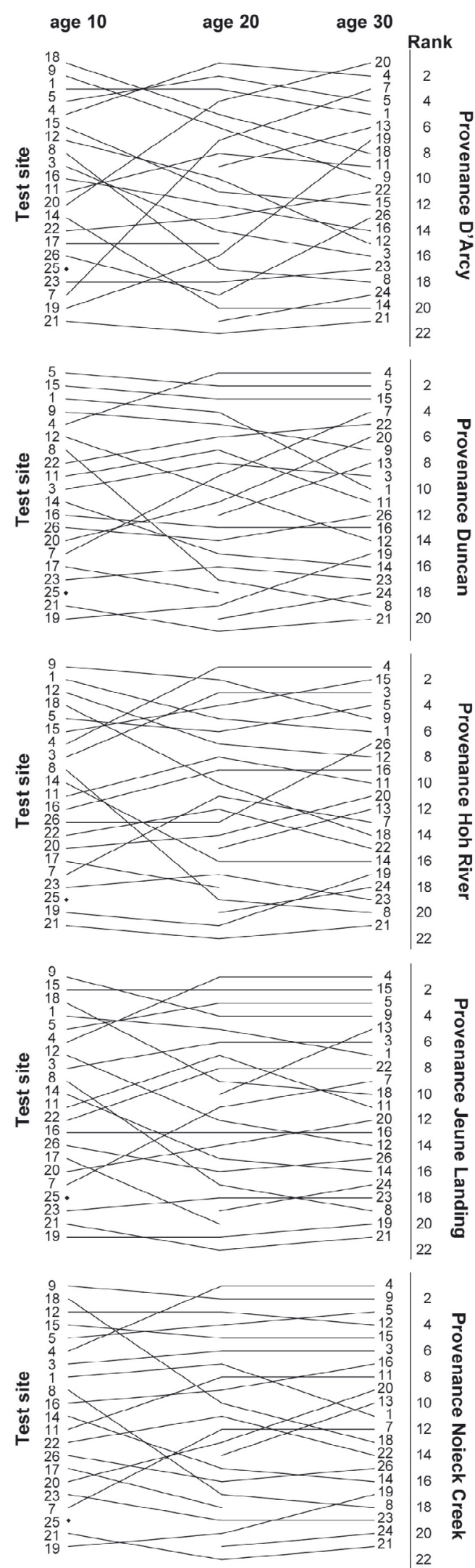

Figure 4. Ranks of five common provenances tested at all sites in EP 599.03 at age 10, 20, and 30; see Table I for site names. 
populations originating from or that may be planted in the CDF zone.

The climate encompassed by the Maritime and Submaritime seed planning zones is expected to expand over the next rotation, moving slightly northward and upward, with the Georgia Lowlands unit expanding into the adjacent areas. However, the range of coastal Douglas-fir is essentially contiguous with these units and is not expected to change much (Hamann and Wang, 2006). Nevertheless, refining current seed transfer protocols to ensure optimally adapted populations over time is a key goal of the provincial forest gene resource management strategy, and maintaining a series of provenance trials is an integral tool to ensure that goal can be met.

\section{CONCLUSIONS}

Managing to minimize the risk associated by maladaptation of forest tree populations to climate change expected over the next rotation requires careful analysis and interpretation of available data from provenance trials. This information must be interpreted in the context of each species' physiology and ecological amplitude. Climate models can predict the expected distribution of species over future periods using a range of projected scenarios. The inherent uncertainty in these predictions, however, requires managers of forest genetic resources to adopt a balance between a traditional conservative approach that minimizes risk in the short term and a proactive approach using the best available information to plan for resilient and productive forests over the longer term.

Our results indicate that seed transfer guidelines for coastal Douglas-fir in British Columbia are adequate with respect to the delineation of seed planning zones, but more flexibility can be achieved by permitting additional elevational transfer between high and low elevations between ecologically similar sites. Relaxing latitudinal transfer limits up to an additional degree north and south from the current limits, on sites of similar quality to the location of origin, is also likely to accommodate more flexibility in terms of adaptation without compromising growth.

Acknowledgements: Thanks to C. Ying, C.-Y. Xie, N. Ukrainetz, W. Bergerud, and A. Yanchuk for review comments, P. Ott for model advice, and D. Ashbee for site information.

\section{REFERENCES}

Burdon R.C., 1977. Genetic correlation as a concept for studying genotype-environment interaction in forest tree breeding. Silvae Genet. 26: 168-175.

Campbell R.K., 1979. Genecology of Dougals-fir in a watershed in the Oregon Cascades. Ecology 60: 1036-1050.

Campbell R.K., 1986. Mapped genetic variation of Douglas-fir to guide seed transfer in southwest Oregon. Silvae Genet. 35: 85-96.

Campbell R.K. and Sugano A.I., 1993. Genetic variation and seed zones of Douglas-fir in the Siskiyou National Forest. USDA For. Serv., Pacific Northwest Research Station, Portland, OR. PNW-RP-455, $21 \mathrm{p}$.

Ching K.K. and Bever D., 1960. Provenance study of Douglas-fir in the Pacific Northwest region. I. Nursery performance. Silvae Genet. 9: $11-17$.
Ching K.K. and Hinz P.N., 1978. Provenance study of Douglas-fir in the Pacific Northwest region. III. Field performance at age twenty years. Silvae Genet. 27: 229-233.

Christophe C. and Birot Y., 1979. Genetic variation within and between populations of Douglas fir. Silvae Genet. 28: 197-206.

Hamann A. and Wang T.L., 2005. Models of climatic normals for genecology and climate change studies in British Columbia. Agric. For. Meteorol. 128: 221-211.

Hamann A. and Wang T., 2006. Potential effects of climate change on ecosystem and tree species distribution in British Columbia. Ecology 87: 2773-2786.

Hermann R.K. and Lavender D.P., 1968. Early growth of Douglas-fir from various altitudes and aspects in southern Oregon. Silvae Genet. 17: $143-151$.

Irgens-Moller H., 1957. Ecotypic response to temperature and photoperiod in Douglas-fir. For. Sci. 3: 79-83.

Klinka K., Worrall J., Skoda L., and Varga P., 2000. The distribution and synopsis of ecological and silvical characteristics of tree species of British Columbia's forests. Canadian Cartographics, Coquitlam, B.C., $180 \mathrm{p}$.

Mátyás C., 1994. Modeling climate change effects with provenance test data. Tree Physiol. 14: 797-804.

Nuszdorfer F.C., Klinka K., and Demarchi D.A., 1990. Coastal Douglasfir Zone. In: Ecosystems of British Columbia. Min. For., Victoria, B.C., Special Rep. 6, p. 81-93.

O'Neill G.A., Hamann A., and Wang T., 2008. Accounting for population variation improves estimates of the impact of climate change on species' growth and distribution. J. Appl. Ecol. 45: 1040-1049.

Province of British Columbia, 2005 [amended 2007]. Chief forester's standards for seed use. Standard under the Forest and Range Practices Act, S.B.C. 2002, S.169 (1).

Rehfeldt G.E., 1977. Growth and cold hardiness of intervarietal hybrids of Douglas fir. Theor. Appl. Genet. 50: 3-15.

Rowe K.E. and Ching. K.K., 1973. Provenance study of Douglas-fir in the Pacific Northwest region. Silvae Genet. 22: 115-119.

Schmidt R., 1967. B.C. Forest Service initiates Douglas-fir provenance study. BC Lumberman, March 1967.

Sorensen F.C., 1983. Geographic variation in seedling Douglas-fir (Pseudotsuga menziesii) from the western Siskiyou mountains of Oregon. Ecology 64: 696-702.

Spittlehouse D.L., 2008. Climate change, impacts, and adaptation scenarios: climate change and forest and range management in British Columbia, Min. For. Range, Res. Br., Victoria, B.C., Tech. Rep. 045, $38 \mathrm{p}$.

St. Clair, J.B. and Howe G.T., 2007. Genetic maladaptation of coastal Douglas-fir seedlings to future climates. Glob. Change Biol. 13: $1441-1454$.

St. Clair, J.B., Mandel N.L., and Vance-Borland K.W., 2005. Genecology of Douglas-fir in western Oregon and Washington. Ann. Bot. 96: $1199-1214$.

Stonecypher R.W., 1990. Assessing effects of seed transfer for selected parents of Douglas-fir: experimental methods and early results. Joint Meeting of Western Forest Genetics Association and IUFRO Working Parties, S2.02-05, 06, 12 and 14. Olympia, Wash., USA p. 2.290

Wang T., Hamann A., Yanchuk A., O’Neill G.A., and Aitken S.N., 2006a. Use of response functions in selecting lodgepole pine populations for future climates. Glob. Change Biol. 12: 2404-2416.

Wang T., Hamann, A., Spittlehouse D., and Aitken S.N., $2006 \mathrm{~b}$. Development of PRISM based scale-free climate data for western Canada. Int. J. Climat. 26: 383-397.

White T.L. and Ching K.K., 1985. Provenance study of Douglas-fir in the Pacific Northwest region. IV. Field performance at age 25 years. Silvae Genet. 34: 84-90.

Ying C.C., 1990. Adaptive variation in Douglas-fir, Sitka spruce and true fir: a summary of provenance research in coastal British Columbia (abstract). Joint Meeting of Western Forest Genetics Association and IUFRO Working Parties, S2.02-05, 06, 12 and 14. Olympia, Wash., USA p. 2.387 